\title{
Pendulum swings from hypo- to hyperthyroidism: thyrotoxicosis after severe hypothyroidism after neck irradiation in a patient with a history of Hodgkin's lymphoma
}

Krzysztof Lewandowski, Affl

Corresponding Affiliation: Aff1

Katarzyna Dabrowska,, Affl

Jacek Makarewicz, $\stackrel{\text { Aff2 }}{\text {. }}$

Andrzej Lewinski,, Affl

ArticleInfo

\begin{tabular}{|l||l||l||}
\hline \hline ArticleID & $:$ & 206 \\
\hline \hline ArticleDOI & $:$ & $10.1186 / 1756-6614-8-S 1-A 18$ \\
\hline \hline ArticleCitationID & $:$ & A18 \\
\hline \hline ArticleSequenceNumber & $:$ & 18 \\
\hline \hline ArticleCategory & $:$ & Meeting abstract \\
\hline \hline ArticleFirstPage & $:$ & 1 \\
\hline \hline ArticleLastPage & $:$ & 3 \\
\hline \hline ArticleHistory & $:$ & $\begin{array}{l}\text { RegistrationDate } \\
\text { OnlineDate }\end{array}$ \\
\hline \hline & & $\begin{array}{l}\text { Lewandowski et al; licensee BioMed Central Ltd.2015 } \\
\text { This article is published under license to BioMed Central } \\
\text { Ltd. This is an Open Access article distributed under the } \\
\text { terms of the Creative Commons Attribution License } \\
\text { (http://creativecommons.org/licenses/by/4.0), which permits }\end{array}$ \\
ArticleCopyright & $:$ & $\begin{array}{l}\text { unrestricted use, distribution, and reproduction in any } \\
\text { medium, provided the original work is properly cited. The } \\
\text { Creative Commons Public Domain Dedication waiver } \\
\text { (http://creativecommons.org/publicdomain/zero/1.0/) applies } \\
\text { to the data made available in this article, unless otherwise } \\
\text { stated. }\end{array}$ \\
\hline
\end{tabular}

Aff1

Department of Endocrinology and Metabolic Diseases, Polish Mother's Memorial Hospital Research Institute, The Medical University of Lodz, Lodz, Poland

Aff2

Department of Nuclear Medicine and Oncological Endocrinology, Zgierz District Hospital, Zgierz, Poland

Spring School of Thyroidology organized by the Polish Thyroid Association 2014: abstracts of invited lectures

Spring School of Thyroidology organized by the Polish Thyroid Association 2014

Miedzyzdroje, Poland 
Publication of this supplement was funded by the Polish Thyroid Association. The Supplement Editors declare that they have no competing interests.

Meeting abstracts

Andrzej Lewinski

Mariusz Stasiolek

\section{Case presentation}

A 27-year old female presented with clinical and biochemical thyrotoxicosis (TSH $0.01 \mu \mathrm{IU} / \mathrm{mL}$ (ref. range: 0.27-4.2 $\mu \mathrm{IU} / \mathrm{mL}$ ); FreeT4 $1.58 \mathrm{ng} / \mathrm{dL}$ (ref. range 0.98-1.63 ng/dL); FreeT3 4.56 pg/mL (ref. range 2.6-4.4 pg/mL). Clinical examination revealed tachycardia at about 100 beats/minute and no obvious goitre. Autoimmune profile was suggestive of Graves' disease (anti-TSH-receptor antibodies (aTSHR) $16.69 \mathrm{IU} / \mathrm{L}$ (ref. 0-1.75), anti-thyroid peroxidase antibodies (aTPO) $1780 \mathrm{IU} / \mathrm{mL}$ (ref.: 0-34 IU/mL). The patient had a history of Hodgkin's lymphoma, diagnosed and treated with chemo- and radiotherapy (including the neck) at the age of 18. At the age of 20 she developed severe hypothyroidism (TSH>100 $\mu \mathrm{IU} / \mathrm{ml})$, though with high titres of both aTPO $(150 \mathrm{IU} / \mathrm{mL})$ and aTSHR (37.56 IU $/ \mathrm{mL})$ antibodies. Thyroid function tests normalised after treatment with L-thyroxine (100 $\mu \mathrm{g} \mathrm{od})$. At the age of 26 she became "anxious" and experienced "heart palpitations". She was found to have suppressed $\mathrm{TSH}$, that remained suppressed even when the dose of L-thyroxine was reduced and then discontinued. After further four months she was found to have raised free T3 (see above). Thyroid scintigraphy revealed a normal and homogenous iodine uptake (41\%). The patient responded very well to treatment with low dose thiamazole (10 $\mathrm{mg}$ od). As subclinical thyrotoxicosis persisted after discontinuation of thiamazole, she was eventually referred for treatment with radioiodine.

\section{Discussion}

Thyroid dysfunction is one of the most common abnormalities seen after radiotherapy for Hodgkin's disease that includes the neck [1]. Primary hypothyroidism, the most common radiation-induced thyroid dysfunction, appears in $20-30 \%$ of patients who had therapeutic radiotherapy administered to the neck region, and usually occurs within the first 5 years after therapy (peak 2-3 years after treatment) [1]. Irradiation of the thyroid may also increase the risk of Graves' disease (relative risk 7.2-20.4\%), or Graves' ophthalmopathy, thyroiditis, benign adenomas and thyroid cancer. The aetiology of radiation-induced thyroid dysfunction includes vascular damage, parenchymal cell damage and auto-immune reactions [1]. According to some authors, thyroiditis observed in Hodgkin's disease may be the result of immune regulation disorders in Hodgkin's disease [2]. Our case illustrates that after neck irradiation, severe hypothyroidism can be followed by thyrotoxicosis. In both situations, aTSHR were elevated. There are two types of aTSHR: thyroid stimulating antibody (TSAb) and TSH-stimulation blocking antibody (TSBAb). TSBAb blocks TSH-stimulation of the thyroid and causes hypothyroidism. TSAb stimulates the thyroid and causes Graves' hyperthyroidism. In our opinion, change of thyreometabolic state is possible, because in this case there was a gradual switch from a TSH receptor blocking antibodies (TSBAb) into TSH receptor stimulating antibodies(TSAb). In some patients, TSAb and hyperthyroidism develop unexpectedly after hypothyroidism that is caused by TBAb [3]. Also, in some hypothyroid patients after irradiation of the neck with Hodgkin's disease developed hyperthyroiditism [4]. This shift in thyroid function occurs rarely [ $\underline{3}, \underline{4}$ ]. A number of mechanisms may be involved in switching from TBAb to TSAb. Significantly, thyroxine treatment in some patients is associated with increased TSAb that in extreme cases might lead to development of hyperthyroidism in hypothyroid patients [3]. There are reports that after neck irradiation Graves' disease may develop in patients receiving thyroxine, and $33 \%$ of the patients with Graves' hyperthyroidism had received thyroxine before its onset [4]. Therefore thyroid hormone-replacement therapy in patients with hypothyroidism after irradiation of the neck does not eliminate risk of later thyroid abnormalities. 


\section{Acknowledgement}

Verbal consent was obtained from the patient for presentation of the above case for postgraduate and student training purposes.

\section{References}

1. Jereczek-Fossa BA, Alterio D, Jassem J, Gibelli B, Tradati N, Orecchia R: Radiotherapy-induced thyroid disorders. Cancer Treat Rev 2004,30(4):369-384. 10.1016/j.ctrv.2003.12.003

2. Illés A, Bíró E, Miltényi Z, Keresztes K, Váróczy L, András C, et al.: Hypothyroidism and thyroiditis after therapy for Hodgkin's disease. Acta Haematol 2003,109(1):11-17. 10.1159/000067269

3. McLachlan SM, Rapoport B: Thyrotropin-blocking autoantibodies and thyroid-stimulating autoantibodies: potential mechanisms involved in the pendulum swinging from hypothyroidism to hyperthyroidism or vice versa. Thyroid 2013,23(1):14-24. 10.1089/thy.2012.0374

4. Hancock SL, Cox RS, McDougall IR: Thyroid diseases after treatment of Hodgkin's disease. $N$ Engl J Med 1991,325(9):599-605. 10.1056/NEJM199108293250902 